Research Article

\title{
Evaluation of Managerial Overconfidence, Cash Holding, and Investment Efficiency in Companies
}

\author{
Abdorreza Asadia (D, Maryam Oladia, and Mohammad Ghasem Aghela \\ Department of Management, Neyshabur Branch, Islamic Azad University, Neyshabur, Iran \\ Correspondence should be addressed to Abdorreza Asadia; a.asadi@iau-neyshabur.ac.ir
}

Received 21 October 2021; Revised 20 November 2021; Accepted 23 November 2021; Published 31 December 2021

Academic Editor: Miaochao Chen

Copyright ( 92021 Abdorreza Asadia et al. This is an open access article distributed under the Creative Commons Attribution License, which permits unrestricted use, distribution, and reproduction in any medium, provided the original work is properly cited.

\begin{abstract}
Managers' overconfidence leads to overestimating their ability to manage cash sources. Holding more cash may result in overinvestment in projects and investment inefficiency consequently. The present study aims to investigate the effect of cash holding on investment efficiency with the moderating role of managerial overconfidence in Iranian companies. All listed firms in Tehran Stock Exchange, excluding banks, insurance, pension funds, and financial intermediaries, are included in the research. We have used data from financial statements of 91 companies over the period from 2010 to 2018 and conducted multiple regression models to test the hypotheses based on pooled and panel data set with fixed effects. The results indicate a positive relationship between managerial overconfidence and cash holding. The effect of cash holding on investment efficiency turns out to be significantly negative. Furthermore, managerial overconfidence has a significant moderating effect on the relation of the variables. This study is almost the first one, which has been done in emerging markets, so the study's findings not only contribute to the existing literature on managerial overconfidence and investment efficiency but also assist policymakers, managers, and investors in making effective decisions.
\end{abstract}

\section{Introduction}

Nowadays, the separation of firms' ownership and management has increased agency problems and consequently increased agency costs for the shareholder. To solve the problem and align the owners and managers' interests, the idea of giving stock options to managers has been raised. Given that the managers' compensation is usually determined by the company's profitability and the assumption that everyone seeks to maximize their benefits, it is assumed that managers aim to exaggerate earnings opportunistically. Therefore, when excess cash is generated due to the company's activities, managers tend to misuse those funds for irrational investments, for instance, leading to overinvestment, which is a kind of investment inefficiency [1]. Managerial overconfidence is one of the most critical findings in the field of judgment and decision-making psychology. Psychologists have found that people overestimate their ability to perform tasks correctly. This is directly related to how important a task is to the person. Heaton [2] offered two definitions of overconfidence. First, people overestimate their abilities. Second, people see an event as more definite than it is. Psychologists have also proposed that people prioritize outstanding information when analyzing and making decisions.

Kaplan et al. [3] introduced detailed measurement of CEO personalities to determine the nature of CEO overconfidence as it is commonly used. The measurements, widely used in the behavioral corporate finance and economics literature, are significantly related to several specific characteristics associated with overconfident individuals and individuals with lower ability. Some research reveals a negative relationship between social ties among firms' managers and investment efficiency in knowledge-based economy indicators using a fuzzy and neural network method $[4,5]$. Manager overconfidence can aggravate this association. It means that social ties between inside and outside managers decline board independence, which negatively affects an optimal investment decision. Therefore, shareholders must effectively control the firm's managers, who are overconfident in decision-making when board members are socially tied to each other [6]. It is essential to 
examine the effects of managerial overconfidence on companies' activities. This behavioral bias can lead to costly and incorrect decisions and irrational investment and financing policies [7]. Therefore, it is necessary to prevent the opportunistic behaviors of managers to some extent by examining the factors affecting the efficiency of investment.

One of the most important managers' decisions is related to cash management. Cash management is one of the essential components of managing the financial sources of companies. Proper access to cash can help companies continue their operations, resulting in maintaining and increasing market share, timely investments, and business reputation. The lack of cash reserves can significantly jeopardize the company's potential growth because of the competitive environment in which companies operate [8]. However, Azimi Yancheshme and Shamohammadi Ghahsareh [9] posit that there is a negative relationship between firms' market share and the amount of cash holding in the Iranian capital market, whereas the research studies indicate that increasing the efficiency investments using available cash can ensure companies' development by creating new values for shareholders. Carrying out industrial projects requires the necessary financial sources and cash, and companies are forced to use proper cash management $[10,11]$. On the other hand, according to agency theory, free cash in the hands of managers can be used in inefficient investments, resulting in increased agency costs for shareholders.

The present study would have at least three practical results. First, the study examines the relationship between managerial overconfidence and cash holding to help expand the literature on corporate cash management at the individual level (managerial overconfidence) rather than at the company or industry level. Second, investigating the relationship between cash holding and investment efficiency can provide companies' managers with optimal use of free cash and internal sources and explain the effects of the sources on investment inefficiency and increasing shareholder interests. Finally, the research helps investors and shareholders better understand the factors affecting the inefficiency of investment and cash holding problems for overconfident managers. In this regard, the objective of the research is to answer the question, whether there are significant relationships between managerial overconfidence, cash holding, and investment efficiency.

\section{Literature Review and Hypotheses Development}

The literature of behavioral finance confirms the field of theoretical and empirical research on the irrationality of some behaviors of managers and their impact on corporate financial decisions for consumers [12]. For example, as a cognitive bias in psychology, managers' overconfidence influences companies' investment and financial decisions. Studies have shown that managers, because of cognitive biases, make investments that deviate from maximizing wealth for shareholders. In this regard, managers' overconfidence exaggerates financial performance by overestimating future cash flows and companies' profitability [13]. This is often because managers are generally optimistic about performance results or their success rate [14]. Theoretical and empirical studies have shown that overconfidence has a significant impact on the decisionmaking of companies' managers. Managerial overconfidence also affects profit recognition and the book value of assets and liabilities. Overconfident managers overestimate the future profitability of the company's projects, which can result in overinvesting. They may also delay the recognition of losses, having optimistic estimations in determining the value of assets [15]. Graham and Harvey [16] showed that most managers believe that they have a remarkable ability to control financing decisions and positively influence their business performance. Managerial overconfidence can affect the company's risktaking behavior. Ahamdi et al. [17] predicted economic growth using machine learning methods. Kim [18] has introduced management's ability level as a more proper measure of overconfidence, distinguishing between high-performing and low-performing overconfident management. The finding suggests that only low-ability overconfident management is related to a higher likelihood of going-concern modifications for performance. This finding indicates that the overconfidence measure currently implemented is improved by refinement to distinguish between high-ability and low-ability management. Malmendier and Tate [19] consider the capital market to be efficient. Two types of managers operate rational managers and overconfident managers. Both types of managers seek to maximize shareholder wealth. Their only difference is how to forecast firms' future cash flows. The overconfident managers generally overestimate the company's future cash flows since they believe that their company is undervalued in the capital market. On the other hand, they do not correctly estimate the cost of capital and the expected return of creditors and stockholders for a firm's external financing [11, 20]. Malmendier and Tate [21] state that managerial overconfidence increases the sensitivity of companies to invest in operating cash so that the managers invest according to the conditions of financial constraints. As a result of the high cost of external funding, overconfident managers keep more cash because they believe that they are extremely capable of handling cash, trying to mitigate the potential underinvestment problem by keeping additional cash. Holding other variables constant, Aktas et al. [22] revealed a strong positive relationship between management overconfidence and firms' cash holding. They claim that companies with overconfident managers on the board have higher cash holdings and overvalue them than companies with rational managers. Overall, the results show that managerial overconfidence has a positive impact on cash holdings. In this case, the theory that external financing is costly dominates the overinvestment hypothesis of management overconfidence.

Overconfident managers are more likely to make challenging and risky investments than others. Therefore, companies with such managers invest more in $\mathrm{R} \& \mathrm{D}$ activities and innovations [23]. According to Fuckander and Wang [24], the capital market values cash holdings more highly for companies with more confident managers than other firms. This means that companies with such managers, by using cash assets, have a more remarkable ability to create value for future investments compared to other ones. Chen et al. [23] explain that the positive association between management overconfidence and cash holdings is attributable to the investment status of companies. This 
relationship is less affected by traditional cash holding incentives derived from agency and tradeoff theories. Accordingly, companies with high levels of management overconfidence are more likely to keep significant amounts of cash on hand while still making risky investments.

Researchers also show that overconfident managers manipulate the operating cash flow report because they believe that its financial health depends on high cash flows $[25,26]$. On the other hand, there are some financial studies about the application of robust modal regression and renewable quantile regression for evaluating massive investments datasets [27, 28]. Yang and Kim [29] showed that overconfident managers manipulate the level of operating cash flows for financial reporting purposes as well. Managers who behave rationally and present negative cash flows positively in financial statements have greater control over cash flow reporting than overconfident managers. However, Sarlak et al. [30] found that, in the case of Iranian companies, overconfident managers are less inclined to hold cash due to irrational beliefs in their capabilities and ignoring the demand for cash.

$\mathrm{Wu}$ et al. [31] studied the relationship between strategic contributions and environmental malfeasance. Regarding the overconfidence of professional and nonprofessional managers, Xin et al. [32] showed that professional and experienced managers are more overconfident than nonprofessional and inexperienced managers in performing many of their tasks, including cash holding identifying trends, and predicting price fluctuations. Frank and Goyal [33] found that managers may be overly optimistic about the future returns of projects and tend to overinvest. As a result, they do not always follow the pecking order theory of financing. Many research shows that holding excess cash would have many adverse effects on business and shareholder benefits, such as low return on assets, increased cost of capital, and devaluation of the company [34-37]. Rettl [38] stated that companies with more investment opportunities should hold more cash. Shareholder returns will be reduced if managers waste money on low-value projects. As a result, putting vast amounts of money in the control of incompetent managers would lead to a high level of investment in projects with negative net present value reducing the company's value. According to the agency perspective, Javadi et al. [39] investigated the association between uncertainty in economic policy and corporate cash holding in 19 non-US countries. They realize a robust negative relationship between the variables. The results provide evidence that the decrease in cash holdings is moderated by shareholders' ability to force managers to disgorge cash that fits consistently within the agency framework. In general, the results show that the reduction of cash holding helps to reduce the agency problems in conditions of political uncertainty. Root and Yung [40] integrate agency and product market prospects of cash holdings. They observed that high organizational capital (OC) firms hold less cash than low OC firms by controlling the product market. They believe that the agency cash holding problem does not conflict with a product market view of cash. The results show that high OC firms have higher cash holdings, take more risk, have lower leverage, lower total shareholder payouts, and have higher future growth prospects. Moreover, the finding indicates that product market factors such as market concentration and import intensity are positively associated with cash holdings and OC, and cash holdings are positively associated with firm value. Xiang et al. [41] investigated factors influencing the use of Fintech banking by Chinese smaller businesses. Bhuiyan and Hooks [42] showed that companies with at least one manager with a doubtful reputation on the board are more likely to retain cash. Such companies tend to invest heavily in projects. High cash holdings and the decreased cost of external financing can improve the internal financial flexibility of the company. On the other hand, managers can use the cash holdings to pursue their interests and reduce the value of the company through investing large sums of money in unprofitable projects [43]. According to Yang et al. [44], tightening monetary policy reduces corporate investment while holding more cash can mitigate its impact. Cash assets play a vital role for companies with financial constraints and nonstated owned companies. Ma and Bennett [45] examined the relationship between students' perceived employability, academic engagement, and stress in higher finance management. Taghizadeh and Ahmadi [46] exanimated the relationship between the KBE component and economic growth using statistical methods. Managers who are not overconfident or optimistic are hesitant to take too many risks and delay completing new projects until more reliable information is available. In contrast, overconfident and optimistic managers would not take risks before making investment decisions [47]. Managers and shareholders will benefit from risky projects if they are successful. However, Borrowers will face risks as a result of low investment. In contrast, overconfident managers should support shareholders and increase the company's value [48].

Overconfident managers prefer to overinvest the excess free cash flow. However, in the case of limited and insufficient cash for investments, they tend to limit investment projects instead of capital equity issuance, so limited cash and debt burden would avoid overinvestment by the managers [19]. Nguyen et al. [49] studied Vietnamese companies. They found that the overconfidence feature has a beneficial impact on corporate investment. Companies with overconfident managers are less likely to invest despite having large cash flows. March and Shapira [50] found that overconfident managers may have the illusion of control that their business empires are constantly expanding, underestimating investment risks while overestimating revenue. Heaton [2] noted that ignoring asymmetric information and agency costs, managerial overconfidence is still correlated with free cash flows. At different levels of free cash flow, overconfidence can lead to either underinvestment or overinvestment. Gole and Thakur [51] found that overconfidence can partially alleviate previously created underinvestment. Wang et al. [52] also observed a positive relationship between managerial overconfidence and firms' overinvestment. Li et al. [53] showed that when managers are overconfident, they overestimate good investment opportunities and subconsciously magnify their benefits but minimize the likelihood of adverse events. This irrational behavior forces managers to ignore market factors, which affects the accuracy of their future expectations and leads to continued investment in unnecessary projects. Overinvestment and underinvestment indicate investment inefficiency 
and occur due to the conflicts of interests between managers and shareholders.

Gao et al. [54] have suggested that firms' media coverage can affect investment efficiency by reducing underinvestment and increasing overinvestment. In firms with more significant information asymmetry and weaker corporate governance, the negative association between media coverage and underinvestment is stronger. At the same time, the positive impact of media coverage on overinvestment is determined by media-induced CEO overconfidence. On the other hand, investment and noninvestment-related news coverage decrease underinvestment. In contrast, noninvestment-related news coverage is more influential in increasing overinvestment. Eventually, firms' media coverage affects investment efficiency through its information dissemination. Overinvestment maximizes the personal interests of managers but reduces the value of the company severely $[55,56]$. Stoughton et al. [57] prove that companies prefer to invest their profits in innovative activities to maintain a monopoly. Internal cash flows are considered low-cost sources.

Ben-David et al. [58] conducted a study to examine the effect of managers' overconfidence on corporate financial policies. Their results showed that companies with highly confident managers make overinvestments and prefer longterm projects to short-term ones. Their results also indicated that overconfident managers are less willing to share dividends due to their preference for internal financing. Ishikawa and Takahashi [59] found that overconfident executives were less likely to use stock issuance than debt financing when external funds were needed. They believed that it would lead to a lower valuation of equity than the debt, leading to increased company's financial leverage. Vosoughi et al. [60] investigated the relationship between financial distress and investment efficiency for Iranian listed companies throughout 2008-2013. They found out that there is a relationship between financial distress and investment efficiency, and institutional ownership has a positive effect on the relationship between the variables. However, for managerial ownership, no significant effect can be observed on the relation of the two variables. Peng et al. [61] have analyzed the Rectifier Blockage on Gas Extraction effectively. Abdoli and Gholami [62] studied the relationship between managerial overconfidence and cost stickiness in Tehran Stock Exchange. They found that managerial overconfidence had a significant positive relationship with the stickiness of administrative, distribution, and selling costs. Managerial overconfidence also significantly affects earnings forecast errors [63]. Hasani Alghar and Rahimian [64] assert that managerial overconfidence significantly affects debt maturity structure, in which overconfident managers take shorter debt maturity by applying the higher percentage of shortterm debt. Damoori and Ghadakfroshan [65] also suggested that financial policies have a significant impact on investment efficiency. In addition, financial policies and investment efficiency have different effects on companies with different values. Bozorg Asl et al. [66] showed that the managers' overconfidence and institutional ownership significantly affect firms' leverage. The evidence proposed that institutional ownership has a significant adverse effect on the relationship between managers' overconfidence and corporate leverage in Iran. Peng et al. [67] have studied forecasting daily natural gas using extended short-term memory technique. Salehi et al. [68] have examined the effect of managerial ability on product market competition and corporate investment decisions, risk-taking, and investment efficiency for Iranian public companies during 2011-2015. The results suggested that market competition discourages managers from investing in risky projects. Moreover, the managerial ability does not affect the relationship between product market competition and investment decisions.

Ghorbani and Korzeniowski [69] offered a Call Option Pricing CT solution with linear capital hedging for a random rate of interest simulation using the CIR Method. Qiao et al. [70] have predicted the US electricity production using a novel hybrid Wavelet. Ahmadi et al. [71] have predicted the GDP factors based on knowledge-based economy using Machine Learning methods. Ghorbani et al. [72] have used random Interest for pricing investment. Salehi et al. [68] investigated the effects of managerial overconfidence on conditional conservatism and natural earnings management in Iran. Using a sample of 143 listed firms over the eight years of 2008 to 2015, they found out that there is a negative relationship between managerial overconfidence and conditional conservatism. Furthermore, the findings suggested that managerial overconfidence is negatively correlated with natural earnings management. The results indicate that when firms' managers encounter financial problems, they are not encouraged to take natural earnings management. Qiao et al. [73] have forecasted the Underwater object using local wavelet and neural network. Also, Qiao et al. [74] have predicted the short-term PM10 using wavelet transform. Salehi et al. [75] aimed to study the relationship between some corporate factors and managerial entrenchment in companies listed on Tehran Stock Exchange. The results indicated a significant relationship between four firms' characteristics (including natural earnings management, predictable earnings management, institutional ownership, and board independence) and managerial entrenchment. Ghorbani and Korzeniowski [76] investigated option costing by using a linear investing approach based on sparse selling of the underlying securities. Ahmadi et al. [77] have used a genetic programming model based on knowledge-based economy factors to assess Iran's GDP. Qiao et al. [78] have analyzed a predicted the difference between natural gas and consumption of US customers using wavelet transform. He et al. [1] indicated a positive and significant relationship between overconfidence and internal financing. The results also indicated that internal financing positively affects investment inefficiency and overinvestment, especially when managers are more confident. Also, the relationship between overinvestment and managers' overconfidence in stateowned companies is more significant than in nonstate firms. Empirical research in emerging markets also showed a significant positive relationship between stock liquidity and the investment efficiency of the company. Moreover, by reducing the cost of capital, the relationship between stock liquidity and the investment efficiency of the company is strengthened. Finally, the findings indicated that, with the 
increase of internal funds, the relationship between stock liquidity and investment efficiency of the company increases as well [79]. Also, in another study, Korzeniowski and Ghorbani [80] investigated the put option price connected with using the selling program of the underlying security in a stochastic market environment.

Based on the theoretical foundations and background of the studies, the following hypotheses have been proposed:

H1. Managerial overconfidence has a significant positive effect on the level of the company's cash holding

H2. Holding excess cash significantly decreases the company's investment efficiency

H3. Managerial overconfidence significantly affects the relation between cash holding and the company's investment efficiency

\section{Methodology}

3.1. Sample Selection and Data Sources. The present study is classified as quasiexperimental research with a deductive approach that used a multiple linear regression model through PAA. We focused on all listed companies on Tehran Stock Exchange. However, insurance companies, pension funds, banks, mutual funds, investment companies, and financial intermediaries were excluded. Finally, we have selected 91 companies from 2010 to 2018, with 819 observations as the sample. Companies' financial data came from the Rahavard Novin database and Kodal official market website, adjusted with the audited financial statements figures. We have used Excel and EViews 9 software for preparing and analyzing the information.

\subsection{Research Variables}

3.2.1. Cash Holding $\left(\mathrm{CASH}_{i t}\right)$. Following Yang et al. [44] and Chen et al. [23], we measured the variable using the ratio of cash and short-term investments to book value of assets.

3.2.2. Investment Efficiency (INVEFF $\left.F_{i t}\right)$. For measuring this variable, Biddle et al.'s [81] model is used as follows:

$$
\mathrm{INV}_{\mathrm{it}+1}=\beta_{0}+\beta_{1} \text { Sales Growth }_{\mathrm{it}}+\varepsilon_{\mathrm{it}+1} \text {, }
$$

where $\mathrm{INV}_{\mathrm{it}+1}$ is the ratio of investment in fixed and intangible assets, goods in process, and long-term investments on the book value of total assets for year $t+1$. SalesGrowth ${ }_{\text {it }}$ is measured by the difference between sales $\mathrm{t}_{\mathrm{t}}$ and sales $\mathrm{t}_{\mathrm{t}-1}$ divided by sales in year $\mathrm{t}-1 . \varepsilon_{\mathrm{it}+1}$ is the residual value of the model. Positive residuals mean overinvestment and negative ones show underinvestment, which both indicate investment inefficiency.

After estimating equation (1), following Chen et al. [82] and Mansourfar et al.[83], the inverse of the absolute value of the residuals $\left(\varepsilon_{\mathrm{it}}\right)$ is calculated (as equation (2)) to measure the investment efficiency. Then the more significant the ratio, the more investment efficiency, and vice versa.

$$
\operatorname{INVEFF}_{\text {it }}=\frac{1}{\left|\varepsilon_{i t}\right|} \text {. }
$$

3.2.3. Managerial Overconfidence $\left(M O C_{i t}\right)$. In this study, a dummy variable with zero and one has been used to measure managerial overconfidence. So, suppose that the profit forecasted by management is more than the actual profit. In that case, the variable takes value one, indicating the existence of overconfidence, and takes zero otherwise [66].

3.2.4. Control Variables. We have used control variables in the model following Chen et al. [23]. The variables included firm size (natural logarithm of the book value of total assets), Tobins' q ratio (market value of equity and debts divided by book value of assets), financial leverage (ratio of total debts to total assets), return on assets (ratio of net profit to book value of assets), earning per share (net profit after tax divided by a total number of shares issued), operational cash flow (ratio of net operating cash flow to book value of total assets), and ownership concentration calculated using Herfindahl-Hirschman index as follows:

$$
\mathrm{HHI}=\sum_{i=1}^{N} S_{i j}^{2}
$$

where $S_{i j}$ is the percentage of shares owned by shareholder $i$ in company $j$ and the large scale of this index indicates more concentration and the involvement of a limited number of significant shareholders in the company's ownership structure and vice versa (see Table 1).

\section{Empirical Models}

We have used the following multiple regression models to test the research hypotheses for panel data consisting of 819 observations, according to $\mathrm{He}$ et al. [1]. The models are presented as follows:

$$
\begin{aligned}
& \mathrm{CASH}_{\mathrm{it}}=\beta_{0}+\beta_{1} \mathrm{MOC}_{\mathrm{it}}+\beta_{2} \mathrm{SIZE}_{\mathrm{it}}+\beta_{3} \mathrm{TQ}_{\mathrm{it}}+\beta_{4} \mathrm{LEV}_{\mathrm{it}}+\beta_{5} \mathrm{ROA}_{\mathrm{it}}+\beta_{6} \mathrm{EPS}_{\mathrm{it}}+\beta_{7} \mathrm{CF}_{\mathrm{it}}+\beta_{8} \mathrm{HHI}+\varepsilon_{\mathrm{it}} \text {, } \\
& \mathrm{INVEFF}_{\text {it }}=\beta_{0}+\beta_{1} \mathrm{CASH}_{\mathrm{it}}+\beta_{2} \mathrm{SIZE}_{\text {it }}+\beta_{3} \mathrm{TQ}_{\mathrm{it}}+\beta_{4} \mathrm{LEV}_{\text {it }}+\beta_{5} \mathrm{ROA}_{\mathrm{it}}+\beta_{6} \mathrm{EPS}_{\mathrm{it}}+\beta_{7} \mathrm{CF}_{\mathrm{it}}+\beta_{8} \mathrm{HHI}_{\mathrm{it}}+\varepsilon_{\mathrm{it}} \text {, } \\
& \operatorname{INVEFF}_{i t}=\beta_{0}+\beta_{1} \mathrm{CASH}_{\text {it }}+\beta_{2} \mathrm{MOC}_{\text {it }}+\beta_{3}\left(\mathrm{CASH}_{\mathrm{it}} * \mathrm{MOC}_{\mathrm{it}}\right)+\beta_{4} \mathrm{SIZE}_{\mathrm{it}}+\beta_{5} \mathrm{TQ}_{\mathrm{it}}+\beta_{6} \mathrm{LEV}_{\mathrm{it}}+\beta_{7} \mathrm{ROA}_{\mathrm{it}} \\
& +\beta_{8} \mathrm{EPS}_{\mathrm{it}}+\beta_{9} \mathrm{CF}_{\mathrm{it}}+\beta_{10} \mathrm{HHI}_{\mathrm{it}}+\varepsilon_{\mathrm{it}} \text {. }
\end{aligned}
$$


TABLE 1: Variable definitions.

\begin{tabular}{|c|c|c|}
\hline Variable & Symbol & Variable measurement and definitions \\
\hline Cash holding & CASH & The ratio of cash plus short-term investments to the book value of assets \\
\hline Investment efficiency & INVEFF & The inverse of the absolute value of the residuals $\left(\varepsilon_{\mathrm{it}}\right)$ in the model presented by Biddle et al. [81] \\
\hline $\begin{array}{l}\text { Managerial } \\
\text { overconfidence }\end{array}$ & MOC & $\begin{array}{l}\text { A dummy variable; if the profit forecasted by the management is more than actual value, it takes one } \\
\text { and zero otherwise }\end{array}$ \\
\hline Firm size & SIZE & Natural logarithm of the book value of total assets \\
\hline Tobin’s Q & Q & The total market value of equity plus debts is deflated by the book value of total assets \\
\hline Financial leverage & LEV & Book value of total debts divided by total assets \\
\hline Return on asset & $\mathrm{ROA}$ & The ratio of net profit after tax to book value of total assets \\
\hline Earnings per share & EPS & Net profit after tax divided by a total number of shares issued \\
\hline Operational cash flow & $\mathrm{CF}$ & The ratio of net operating cash flows to the book value of total assets \\
\hline $\begin{array}{l}\text { Ownership } \\
\text { concentration }\end{array}$ & HHI & $\begin{array}{l}\text { Measured by Herfindahl-Hirschman index taking values between zero and one; the larger the index, } \\
\text { the higher ownership concentration }\end{array}$ \\
\hline
\end{tabular}

\section{Empirical Analysis and Results}

5.1. Descriptive Statistics. Table 2 provides summary statistics of the research variables. The mean value of cash holding is 0.079 , indicating that companies tend to hold less than $10 \%$ of cash assets on average. The mean investment efficiency is 0.055 , showing the low efficiency of firms' investments in assets by over/underinvestments. Also the mean values of firm size, TQ, LEV, ROA, EPS, CF, and HHI (as control variables) are 14.062, 2.035, 0.558, 0.134, 0.129, 0.129 , and 0.818 , respectively.

We measure managerial overconfidence as a dummy variable with zero in the presence of overconfidence and zero otherwise. Table 3 shows the frequency of the variables across companies. It is seen that, for $63 \%$ of observations, the variable takes value one indicating the presence of managerial overconfidence. In contrast, for $37 \%$ of observations, the variable takes zero, showing rational management across companies.

5.2. Regression Analysis. Table 4 presents the results of equation (4) to test the first hypothesis, which investigates the effect of managerial overconfidence on cash holding using pooled data. As it is seen, VIF statistic is applied to test the multicollinearity of explanatory variables. According to the values (between one and five), no multicollinearity in the model is concluded. The value of the Chow test also shows that ordinary least squares (OLS) using pooled data is appropriate to test the model.

Also, the estimated coefficient of managerial overconfidence $\left(\beta_{1}=0.016\right)$ shows that the variable has a significant and positive association with cash holding at a $5 \%$ level. Thus the first hypothesis (H1) is supported. This means that the companies with overconfident managers are more inclined to hold cash assets because they believe that they can invest those assets in worthwhile projects. The results are consistent with Malmendier et al. [11]; Aktas et al. [22]; and Chen et al. [23], while being inconsistent with Sarlak et al. [30]. Furthermore, among the control variables, the estimated coefficients of company size $\left(\beta_{2}=0.030\right)$, financial leverage $\left(\beta_{4}=-0.335\right)$, return on assets $\left(\beta_{5}=0.158\right)$, and operating cash flow $\left(\beta_{7}=0.159\right)$ are significant at $1 \%$ level, while the coefficient of ownership concentration $\left(\beta_{8}=0.134\right)$ is
TABLE 2: Descriptive statistics of the variables.

\begin{tabular}{lccccc}
\hline Variables & Obs. & Mean & Std. & Min & Max \\
\hline CASH & 819 & 0.079 & 0.153 & 0.066 & 0.568 \\
INVEFF & 819 & 0.055 & 0.068 & 0.0002 & 0.598 \\
SIZE & 819 & 14.062 & 1.606 & 10.195 & 19.249 \\
TQ & 819 & 2.035 & 1.151 & 0.655 & 5.263 \\
LEV & 819 & 0.558 & 0.196 & 0.131 & 0.949 \\
ROA & 819 & 0.134 & 0.146 & -0.176 & 0.602 \\
EPS & 819 & 0.121 & 0.147 & -0.351 & 0.708 \\
CF & 819 & 0.129 & 0.152 & -0.238 & 0.669 \\
HHI & 819 & 0.818 & 0.152 & 0.050 & 0.998 \\
\hline
\end{tabular}

TABLE 3: Frequency of managerial overconfidence.

\begin{tabular}{|c|c|c|c|}
\hline Variable value & Overconfidence & \multicolumn{2}{|c|}{ Frequency } \\
\hline 1 & Yes & 517 & $63 \%$ \\
\hline 0 & No & 302 & $37 \%$ \\
\hline \multicolumn{2}{|c|}{ Sum } & 819 & $100 \%$ \\
\hline
\end{tabular}

significant at $5 \%$ level as well. The coefficients estimated for Tobin' $\mathrm{q}$ and earnings per share are not significant.

Table 5 tabulates the results of equation (5) to test the second hypothesis $\left(\mathrm{H}_{2}\right)$ to investigate the effect of cash holding on investment efficiency, using panel data with fixed effects. We used VIF to test the multicollinearity of explanatory variables, and the result shows no multicollinearity problem in the model. Moreover, F-statistic equals 4.970 , indicating the significance of the model at a $1 \%$ level. Also, the value of Durbin-Watson indicates no autocorrelation problem. Chow and Hasman's tests indicate that the panel data set and fixed effects are appropriate for estimating the model.

The estimated coefficient of cash holding $\left(\beta_{1}=-0.137\right)$ shows a significant and negative relationship between the variable and investment efficiency at $1 \%$ level. That means an increase in cash holding can significantly decrease companies' investment efficiency. This result suggests that companies that hold more cash tend to invest in more projects. Thus, overinvestment, especially in projects with negative NPV, reduces investment efficiency. Accordingly, the second hypothesis $\left(\mathrm{H}_{2}\right)$ is statistically confirmed as well. The findings are consistent with Eljelly [34]; Rettl [38]; and Bhuiyan and Hooks [42]. The results also show that the 
TABLE 4: Results of the pooled OLS regression model for the first hypothesis.

\begin{tabular}{|c|c|c|c|}
\hline \multicolumn{4}{|c|}{ Dependent variable: cash holding } \\
\hline Variable & Coefficient & $t$-value & VIF \\
\hline $\mathrm{C}$ & -0.099 & -0.397 & - \\
\hline MOC & 0.016 & $2.112^{* *}$ & 1.013 \\
\hline SIZE & 0.030 & $2.683^{* * *}$ & 1.074 \\
\hline TQ & 0.003 & 1.204 & 1.434 \\
\hline LEV & -0.335 & $-9.167^{* * *}$ & 1.440 \\
\hline ROA & 0.158 & $3.480^{* * *}$ & 3.543 \\
\hline EPS & 0.043 & 1.400 & 1.976 \\
\hline $\mathrm{CF}$ & 0.159 & $2.785^{* * *}$ & 1.464 \\
\hline HHI & 0.134 & $2.321^{* *}$ & 1.032 \\
\hline $\mathrm{AR}(1)$ & 0.832 & $24.857^{* * *}$ & - \\
\hline Industry dummy & - & Yes & - \\
\hline Adj $R^{2}$ & & 0.119 & \\
\hline$F$-value & & $21.674^{* * *}$ & \\
\hline Durbin-Watson & & 2.005 & \\
\hline Chow test & & 1.468 & \\
\hline Hasman test & & - & \\
\hline
\end{tabular}

${ }^{* * *}$ Significant at 0.01 level. ${ }^{* *}$ Significant at 0.05 level.

TABLE 5: Results of fixed effects model for the second hypothesis.

\begin{tabular}{|c|c|c|c|}
\hline \multicolumn{4}{|c|}{ Dependent variable: investment efficiency } \\
\hline Variable & Coefficient & $T$-value & VIF \\
\hline $\mathrm{C}$ & 0.021 & 0.027 & - \\
\hline $\mathrm{CASH}$ & -0.137 & $-5.081^{* * *}$ & 1.602 \\
\hline SIZE & 0.006 & 0.657 & 1.075 \\
\hline TQ & 0.003 & $1.918^{*}$ & 1.446 \\
\hline LEV & -0.046 & $-1.913^{*}$ & 1.788 \\
\hline ROA & -0.061 & $-2.417^{* *}$ & 3.564 \\
\hline EPS & -0.0009 & -0.060 & 2.026 \\
\hline $\mathrm{CF}$ & 0.817 & $3.946^{* * *}$ & 1.462 \\
\hline HHI & 0.017 & 1.339 & 1.044 \\
\hline $\operatorname{AR}(1)$ & 0.943 & $111.037^{* * *}$ & - \\
\hline Industry dummy & - & Yes & - \\
\hline Adj $R^{2}$ & & 0.144 & \\
\hline$F$-value & & $4.970^{* * *}$ & \\
\hline Durbin-Watson & & 2.064 & \\
\hline Chow test & & $2.571^{* * *}$ & \\
\hline Hasman test & & $14.929^{* * *}$ & \\
\hline
\end{tabular}

*** Significant at 0.01 level. ${ }^{* *}$ Significant at 0.05 level. ${ }^{*}$ Significant at 0.1 level.

coefficients of operating cash flows $\left(\beta_{7}=0.817\right)$ and return on asset $\left(\beta_{5}=-0.061\right)$ are significant at $1 \%$ and $5 \%$ levels, respectively. While the coefficient estimated for leverage $\left(\beta_{4}=-0.046\right)$ and Tobin's $Q\left(\beta_{3}=0.003\right)$ are significant at $10 \%$ level.

Table 6 provides the results of equation (6) to test the third hypothesis $\left(\mathrm{H}_{3}\right)$, which examines the moderating effect of managerial overconfidence on the relationship between cash holding and investment efficiency. The results of VIF indicate that there is no multicollinearity for the independent variables. Moreover, the result of Durbin-Watson also describes the lack of autocorrelation of the error terms.

The results also show that there are significant and negative associations between cash holding $\left(\beta_{1}=-0.040\right)$ and managerial overconfidence $\left(\beta_{2}=-0.011\right)$ with firms' investment efficiency at $5 \%$ and $1 \%$ levels, respectively, which means that any increase in independent variables decreases investment efficiency. High cash holding provides an opportunity for overconfident managers to waste cash by overinvestment in negative value and inefficient projects. On the other hand, the coefficient estimated for the interaction effect of managerial overconfidence and cash holding $\left(\beta_{3}=\right.$ 0.016 ) is significant at the $5 \%$ level, showing that managerial overconfidence has a significant moderating effect on the relationship between cash holding and investment efficiency. That means in companies with overconfident managers, the negative effect of cash holding on investment efficiency mitigates due to overestimating the profitability of projects and future cash flows. Therefore, the third research hypothesis $\left(\mathrm{H}_{3}\right)$ is supported. The findings are consistent with Gervais et al. [47]; Malmendier and Tate [19]; Wang et al. [52]; Li et al. [53]; He et al. [1]; Nguyen et al. [49]; and Lai et al. [84]. Table 6 also shows that the estimated coefficients of control variables $\left(\beta_{4}=-0.002\right)$ and company size 
TABLE 6: Results of fixed effects model for the third hypothesis.

\begin{tabular}{lccc}
\hline \multicolumn{4}{c}{ Dependent variable: investment efficiency } \\
Variable & Coefficient & T-value & VIF \\
\hline C & 0.083 & $3.240^{* * *}$ & - \\
CASH & -0.040 & $-2.185^{* * *}$ & 1.126 \\
MOC & -0.011 & $-2.512^{* * *}$ & 2.911 \\
CASH* MOC & 0.016 & $2.286^{* *}$ & 2.571 \\
SIZE & -0.002 & $-2.684^{* * *}$ & 1.088 \\
TQ & -0.001 & -1.570 & 1.447 \\
LEV & 0.077 & $7.227^{* * *}$ & 1.795 \\
ROA & 0.0005 & 0.035 & 3.566 \\
EPS & 0.009 & 1.183 & 2.037 \\
CF & -0.004 & -0.438 & 1.465 \\
HHI & -0.016 & $-2.018^{* * *}$ & 1.050 \\
AR $(1)$ & 0.143 & $3.951^{* * *}$ & - \\
Industry dummy & - & Yes & - \\
Adj $R^{2}$ & & 0.163 & \\
F-value & & $3.122^{* * *}$ & \\
Durbin-Watson & & 2.024 & \\
Chow test & & $2.755^{* * *}$ & \\
Hasman test & & $13.731^{* * *}$ & \\
\hline
\end{tabular}

${ }^{* * *}$ Significant at 0.01 level. ${ }^{* *}$ Significant at 0.05 level. ${ }^{*}$ Significant at 0.1 level.

$\left(\beta_{6}=0.077\right)$ are significant at $1 \%$ level, while the coefficient of ownership concentration $\left(\beta_{10}=-0.016\right)$ seems to be significant at the $5 \%$ level.

\section{Conclusion and Recommendation}

The present study investigated the effect of companies' cash holding on investment efficiency. It examined the moderating role of managerial overconfidence on the relationship between the variables. Three hypotheses were tested, and the results were presented in previous sections. We found that managerial overconfidence has a significant positive effect on Iranian firms' cash holding. Accordingly, companies with overconfident managers try to meet their financing needs by holding excess cash. They believe that they have more information and the ability to control their internal sources; therefore, they overpredict the future growth opportunities and cash inflows. This tendency is in line with the pecking order theory. Managers prefer internal funds to issuance new debts and equities because they assume that internal cash favors the company due to low cost. The findings of the second hypothesis showed that there is a significant and negative relationship between cash holding and investment efficiency. This means that increasing the free cash available to managers increases agency costs and leads managers to invest more in projects with negative NPV, which reduces investment efficiency. However, financing the company through capital market sources reduces the funds available for managers for inefficient actions. It makes them more accountable for their investment decisions. Therefore, increasing cash holding encourages managers to overinvest in inefficient projects, opposite shareholders' interests. The results of the third hypothesis indicated that managerial overconfidence has a significant moderating role in the relationship between cash holding and investment efficiency.
Overconfident managers reduce investment efficiency by increasing cash holding actions. Because they tend to overestimate their ability and the accuracy of the available information, they overpredict its profitability and future cash flows. Accordingly, they overinvest in projects with negative NPV, resulting in the inefficiency of investments. In the present study, we have included neither variables such as corporate governance, ownership structure, and firms' competitive power in the product market on investment efficiency nor the effect of other behavioral biases such as conservatism and loss aversion on cash holding. These could be considered as limitations of the research.

Accordingly, some recommendations can be made to capital market participants in Iran. Investors are suggested to pay attention to management decisions regarding the holding cash flows and the number of investment projects when investing in companies. Increasing internal cash available for overconfident managers will increase agency costs resulting in low investment efficiency. Corporate shareholders, preeminent ones, are recommended to provide appropriate mechanisms to be informed of the internal sources and process of analyzing investment projects in order to control the managers' decisions. The managers of the companies are also suggested to take a realistic assessment of the future profitability and return of investment projects and consider the country's economic situation and alignment of shareholders' interests. Researchers are also encouraged to study the effect of corporate governance mechanisms and other behavioral biases of managers on firms' investment and decision-making efficiency to provide policies that maximize shareholders' wealth.

\section{Data Availability}

Data are available and can be provided over email, querying directly to the corresponding author at a.asadi@iauneyshabur.ac.ir.

\section{Conflicts of Interest}

The authors declare that they have no conflicts of interest.

\section{References}

[1] Y. He, C. Chen, and Y. Hu, "Managerial overconfidence, internal financing, and investment efficiency: evidence from China," Research in International Business and Finance, vol. 47, pp. 501-510, 2019.

[2] J. B. Heaton, "Managerial optimism and corporate finance," Financial Management, vol. 31, no. 2, pp. 33-45, 2002.

[3] S. N. Kaplan, M. Sorensen, and A. A. Zakolyukina, "What is CEO overconfidence? Evidence from executive assessments," Journal of Financial Economics, 2021, in press.

[4] M. Ahmadi, "A computational approach to uncovering economic growth factors," Computational Economics, vol. 58, pp. 1-26, 2020.

[5] M. Ahmadi and R. Taghizadeh, "A gene expression programming model for economy growth using knowledgebased economy indicators: a comparison of GEP model and ARDL bounds testing approach," Journal of Modelling in Management, vol. 14, 2019. 
[6] Y. J. Kang, H. Y. Lee, H. Y. Park, and J. H. Park, "Social ties, managerial overconfidence, and investment efficiency," Finance Research Letters, Article ID 102300, 2021.

[7] K. Chavoshi, M. Rastegar, and M. Mirzaee, "Examination of the relation between managerial overconfidence and financing policies in Tehran stock exchange," Financial Knowledge of Securities Analysis, vol. 8, no. 25, pp. 29-41, 2015.

[8] Y. Chen and V. Sivakumar, "Invesitigation of finance industry on risk awareness model and digital economic growth," Annals of Operations Research, pp. 1-22, 2021.

[9] M. Azimi Yancheshme and S. Shamohammadi Ghahsareh, "Studying the relationship between cash holdings and market share using dynamic models of companies listed in Tehran stock exchange," Journal of Financial accounting Research, vol. 4, no. 22, pp. 55-72, 2014.

[10] S. C. Myers, "The capital structure puzzle," The Journal of Finance, vol. 39, no. 3, pp. 575-592, 1984.

[11] U. Malmendier, G. Tate, and J. Yan, "Overconfidence and early-life experiences: the effect of managerial traits on corporate financial policies," The Journal of Finance, vol. 66, no. 5, pp. 1687-1733, 2011.

[12] M. Zhuang, W. Zhu, L. Huang, and W.-T. Pan, "Research of influence mechanism of corporate social responsibility for smart cities on consumers' purchasing intention," Library Hi Tech, 2021.

[13] U. Malmendier and G. Tate, "Who makes acquisitions? CEO overconfidence and the market's reaction," Journal of Financial Economics, vol. 89, no. 1, pp. 20-43, 2008.

[14] Z. L. Li, H. P. Zhao, and Y. F. Song, "Empirical research on managerial overconfidence and corporate financing behavior of pecking-order," Journal of Accounting Research, vol. 33, no. 3, pp. 10-40, 2009.

[15] S. Deshmukh, A. M. Goel, and K. M. Howe, "CEO overconfidence and dividend policy," Journal of Financial Intermediation, vol. 22, no. 3, pp. 440-463, 2013.

[16] J. R. Graham and C. R. Harvey, "The theory and practice of corporate finance: evidence from the field," Nankai Business Review, vol. 60, no. 2-3, pp. 187-243, 2001.

[17] M. Ahmadi, S. Jafarzadeh-Ghoushchi, R. Taghizadeh, and A. Sharifi, "Presentation of a new hybrid approach for forecasting economic growth using artificial intelligence approaches," Neural Computing and Applications, vol. 31, no. 12, pp. 8661-8680, 2019.

[18] M. Kim, "Effects of managerial overconfidence and ability on going-concern decisions and auditor turnover," Advances in Accounting, vol. 54, 2021.

[19] U. Malmendier and G. Tate, "CEO overconfidence and corporate investment," The Journal of Finance, vol. 60, no. 6, pp. 2661-2700, 2005.

[20] H. Gao, D. Shi, and B. Zhao, "Does good luck make people overconfident? evidence from a natural experiment in China," in Proceedings of the 31st Australasian Finance and Banking Conference, Sydney, Australia, 2018, November.

[21] U. Malmendier and G. Tate, "Behavioral CEOs: the role of managerial overconfidence," The Journal of Economic Perspectives, vol. 29, no. 4, pp. 37-60, 2015.

[22] N. Aktas, C. Louca, and D. Petmezas, "CEO overconfidence and the value of corporate cash holdings," Journal of Corporate Finance, vol. 54, pp. 85-106, 2018.

[23] Y. R. Chen, K. Y. Ho, and C. W. Yeh, "CEO overconfidence and corporate cash holdings," Journal of Corporate Finance, vol. 62, pp. 34-51, 2020.

[24] M. Faulkender and R. Wang, "Corporate financial policy and the value of cash," The Journal of Finance, vol. 61, no. 4, pp. 1957-1990, 2006.
[25] J. S. Choi and J. H. Noh, "Do Korean listed companies manage reported operating cash flows surrounding the adoption of K-IFRS," Korean Accounting Review, vol. 43, no. 1, pp. 33-80, 2018.

[26] H. S. Chung and S. H. Yang, "Incentives to avoid negative operating cash flow and operating cash flow management," Korean Accounting Review, vol. 43, no. 1, pp. 1-31, 2018.

[27] K. Wang and S. Li, "Robust distributed modal regression for massive data," Computational Statistics \& Data Analysis, vol. 160, Article ID 107225, 2021.

[28] K. Wang, H. Wang, and S. Li, "Renewable quantile regression for streaming datasets," Knowledge-Based Systems, vol. 235, Article ID 107675, 2021.

[29] D. Yang and H. Kim, "Managerial overconfidence and manipulation of operating cash flow: evidence from Korea," Finance Research Letters, vol. 32, 2020.

[30] N. Sarlak, O. Faraji, M. Ezadpour, and Z. Joudaki Chegeni, "CEO over-confidence and corporate cash holdings: emphasizing the moderating role of audit quality," Journal of Accounting and Auditing Review, vol. 25, no. 20, pp. 199-214, 2018.

[31] B. Wu, C. Jin, A. Monfort, and D. Hua, "Generous charity to preserve green image? Exploring linkage between strategic donations and environmental misconduct," Journal of Business Research, vol. 131, pp. 839-850, 2021.

[32] Q. Q. Xin, B. Lin, and Y. C. Wang, "Government control, executive compensation and capital investment," Economic Research Journal, vol. 8, pp. 110-122, 2007.

[33] M. Z. Frank and V. K. Goyal, "Testing the pecking order theory of capital structure," Journal of Financial Economics, vol. 67, no. 2, pp. 217-248, 2003.

[34] A. M. A. Eljelly, "Liquidity-profitability tradeoff: an empirical investigation in an emerging market," International Journal of Commerce and Management, vol. 14, no. 2, pp. 48-61, 2004.

[35] M. C. Jensen, "Agency costs of free cash flow, corporate finance, and takeovers," The American Economic Review, vol. 76, no. 2, pp. 323-329, 1986.

[36] L. Pinkowitz, R. Stulz, and R. Williamson, "Does the contribution of corporate cash holdings and dividends to firm value depend on governance? A cross-country analysis," The Journal of Finance, vol. 61, no. 6, pp. 2725-2751, 2006.

[37] B. Wu, H. Fang, G. Jacoby, G. Li, and Z. Wu, "Environmental regulations and innovation for sustainability? Moderating effect of political connections," Emerging Markets Review, Article ID 100835, 2021.

[38] D. Rettl, Growth Opportunities, Cash Holdings And Payout Policy, Vienna Graduate School of Finance, Vienna, Austria, 2011.

[39] S. Javadi, M. Mollagholamali, A. Nejadmalayeri, and S. AlThaqeb, "Corporate cash holdings, agency problems, and economic policy uncertainty," International Review of Financial Analysis, vol. 77, 2021.

[40] A. Root and K. Yung, "Resolving agency and product market views of cash holdings," Research in International Business and Finance, vol. 59, 2022.

[41] D. Xiang, Y. Zhang, and A. C. Worthington, "Determinants of the use of fintech finance among Chinese small and mediumsized enterprises," in Proceedings of the 2018 IEEE International Symposium on Innovation and Entrepreneurship (TEMS-ISIE), pp. 1-10, IEEE, Beijing, China, March 2018.

[42] M. B. U. Bhuiyan and J. Hooks, "Cash holding and overinvestment behavior in firms with problem directors," International Review of Economics \& Finance, vol. 61, pp. 35-51, 2019. 
[43] K. W. Lee and C. F. Lee, "Cash holdings, corporate governance structure and firm valuation," Review of Pacific Basin Financial Markets and Policies, vol. 12, no. 3, pp. 475-508, 2009.

[44] X. Yang, L. Han, W. Li, X. Yin, and L. Tian, "Monetary policy, cash holding and corporate investment: evidence from China," China Economic Review, vol. 46, pp. 110-122, 2017.

[45] Y. Ma and D. Bennett, "The relationship between higher education students' perceived employability, academic engagement and stress among students in China," Education and Training, vol. 63, 2021

[46] R. Taghizadech and M. Ahmadi, "Statistical and econometrical analysis of knowledge-based economy indicators affecting economic growth in Iran: the new evidence of principal component analysis-tukey and ARDL bound test," Journal of Policy Modeling, 2019.

[47] S. Gervais, J. B. Heaton, and T. Odean, "Overconfidence, investment policy, and executive stock options," in L. Rodney, White Center for Financial Research Working Paper 15, no. 2, 2003.

[48] E. Pikulina, L. Renneboog, and P. N. Tobler, "Overconfidence and investment: an experimental approach," Journal of Corporate Finance, vol. 43, pp. 175-192, 2017.

[49] D. V. Nguyen, D. Q. Dang, G. H. Pham, and D. K. Do, "Influence of overconfidence and cash flow on investment in Vietnam," The Journal of Asian Finance, Economics and Business, vol. 7, no. 2, pp. 99-106, 2020.

[50] J. G. March and Z. Shapira, "Managerial perspectives on risk and risk taking," Management Science, vol. 33, no. 11, pp. 1404-1418, 1987.

[51] A. M. Goel and A. V. Thakor, "Overconfidence, CEO selection, and corporate governance," The Journal of Finance, vol. 63, no. 6, pp. 2737-2784, 2008.

[52] X. Wang, M. Zhang, and F. S. Yu, "CEO overconfidence and distortion of firms' investments: some empirical evidence from China," Nankai Business Review, vol. 11, no. 2, pp. 77-83, 2008.

[53] W. L. Li, G. L. Xie, and J. Y. Hao, “The empirical study on the influence of managerial overconfidence on overinvest behavior," Journal of Shanxi Finance and Economics University, vol. 10, pp. 76-86, 2014.

[54] X. Gao, W. Xu, D. Li, and L. Xing, "Media coverage and investment efficiency," Journal of Empirical Finance, vol. 63, pp. 270-293, 2021.

[55] S. C. Myers, "Determinants of corporate borrowing," Journal of Financial Economics, vol. 5, no. 2, pp. 147-175, 1977.

[56] R. Stulz, "Managerial discretion and optimal financing policies," Journal of Financial Economics, vol. 26, no. 1, pp. 3-27, 1990.

[57] N. Stoughton, K. Wong, and L. Yi, "Investment efficiency and product market competition," Journal of Financial Economics, vol. 25, pp. 325-360, 2015.

[58] B.-D. Itzhak, J. R. Graham, and C. R. Harvey, Managerial Overconfidence and Corporate Policies, No. w13711. National Bureau of Economic Research, Cambridge, MS, USA, 2007.

[59] M. Ishikawa and H. Takahashi, "Overconfident managers and external financing choice," Review of Behavioural Finance, vol. 2, no. 1, pp. 37-58, 2010.

[60] M. Vosoughi, H. Derakhshan, and M. Alipour, "Investigating the relationship between financial distress and investment efficiency of companies listed on the Tehran Stock Exchange," Accounting, vol. 2, no. 4, pp. 167-176, 2016.

[61] S. Peng, Y. Zhang, W. Zhao, and E. Liu, "Analysis of the influence of rectifier blockage on the metering performance during shale gas extraction," Energy \& Fuels, vol. 35, no. 3, pp. 2134-2143, 2021.
[62] M. R. Abdoli and M. Gholami, "The impact of overconfidence managers on cost stickiness," Management Accounting Journal, vol. 9, no. 29, pp. 15-30, 2016.

[63] S. Mehrani and M. Taheri, "Managerial overconfidence and earning forecast errors," Journal of Empirical Research in Accounting, vol. 4, no. 26, pp. 147-164, 2017.

[64] M. Hasani Alghar and N. Rahimian, "The effect of managerial overconfidence on debt maturity structure in listed companies in Tehran stock exchange," Journal of Asset Management and Financing, vol. 6, no. 1, pp. 89-106, 2018.

[65] D. Damoori and M. Ghadakfroshan, "Financial policies and investment efficiency in the companies listed in Tehran stock exchange," Journal of Financial Management Strategy, vol. 6, no. 4, pp. 157-175, 2018.

[66] M. Bozorg Asl, J. Babajani, and A. Kuhkan, "Impact of institutional ownership on the relationship between managers' overconfidence and financial leverage of the companies listed in the Tehran stock exchange," Accounting and Auditing Review, vol. 26, no. 4, pp. 462-498, 2019.

[67] S. Peng, R. Chen, B. Yu, M. Xiang, X. Lin, and E. Liu, "Daily natural gas load forecasting based on the combination of long short term memory, local mean decomposition, and wavelet threshold denoising algorithm," Journal of Natural Gas Science and Engineering, vol. 95, Article ID 104175, 2021.

[68] M. Salehi, M. Lari DashtBayaz, S. Hassanpour, and H. Tarighi, "The effect of managerial overconfidence on the conditional conservatism and real earnings management," Journal of Islamic Accounting and Business Research, vol. 11, no. 3, pp. 708-720, 2020.

[69] N. Ghorbani and A. Korzeniowski, "Adaptive risk hedging for call options under cox-ingersoll-ross interest rates," Journal of Mathematical Finance, vol. 10, no. 4, pp. 697-704, 2020.

[70] W. Qiao, Y. Wang, J. Zhang, W. Tian, Y. Tian, and Q. Yang, "An innovative coupled model in view of wavelet transform for predicting short-term PM10 concentration," Journal of Environmental Management, vol. 289, Article ID 112438, 2021.

[71] M. Ahmadi, S. Jafarzadeh-Ghoushchi, R. Taghizadeh, and A. Sharifi, "Presentation of a new hybrid approach for forecasting economic growth using artificial intelligence approaches," Neural Computing and Applications, vol. 31, no. 12, pp. 8661-8680, 2019.

[72] N. Ghorbani, Option pricing with investment strategy under stochastic interest rates, Ph.D. dissertation, The University of Texas at Arlington, Arlington, TX, USA, 2021.

[73] W. Qiao, Z. Li, W. Liu, and E. Liu, "Fastest-growing source prediction of US electricity production based on a novel hybrid model using wavelet transform," International Journal of Energy Research, 2021.

[74] W. Qiao, M. Khishe, and S. Ravakhah, "Underwater targets classification using local wavelet acoustic pattern and multilayer perceptron neural network optimized by modified whale optimization algorithm," Ocean Engineering, vol. 219, Article ID 108415, 2021.

[75] M. Salehi, M. Lari Dashtbayaz, and M. Motashami, "The effects of corporate characteristics on managerial entrenchment," Iranian Journal of Management Studies, vol. 14, no. 1, pp. 245-272, 2021.

[76] N. Ghorbani and A. Korzeniowski, "Call and put option pricing with discrete linear investment strategy," 2021, http:// arxiv.org/abs/2110.04676.

[77] M. Ahmadi and R. Taghizadeh, "A gene expression programming model for economic growth using knowledgebased economy indicators: a comparison of GEP model and 
ARDL bounds testing approach," Journal of Modelling in Management, vol. 14, no. 1, 2019.

[78] W. Qiao, W. Liu, and E. Liu, "A combination model based on wavelet transform for predicting the difference between monthly natural gas production and consumption of U.S," Energy, vol. 235, Article ID 121216, 2021.

[79] A. Alhassan and A. Naka, "Corporate future investments and stock liquidity: evidence from emerging markets," International Review of Economics \& Finance, vol. 65, no. 3, pp. 69-83, 2020.

[80] A. Korzeniowski and N. Ghorbani, "Put options with linear investment for hull-white interest rates," Journal of Mathematical Finance, vol. 11, no. 1, pp. 152-162, 2021.

[81] G. C. Biddle, G. Hilary, and R. S. Verdi, "How does financial reporting quality relate to investment efficiency?" Journal of Accounting and Economics, vol. 48, no. 2-3, pp. 112-131, 2009.

[82] F. Chen, O.-K. Hope, Q. Li, and X. Wang, "Financial reporting quality and investment efficiency of private firms in emerging markets," The Accounting Review, vol. 86, no. 4, pp. 1255-1288, 2011.

[83] G. Mansourfar, S. Joudi, and E. Poursoleiman, "The role of internal and external dimensions of corporate governance on the relationship between information asymmetry and investment efficiency," Financial Research Journal, vol. 22, no. 2, pp. 227-248, 2020.

[84] S. Lai, X. Li, and K. C. Chan, "CEO overconfidence and labor investment efficiency," The North American Journal of Economics and Finance, vol. 55, 2020. 